\title{
ANALISIS KANDUNGAN POLIFENOL PADA EKSTRAK TUNAS BAMBU BETUNG (Dendrocalamus asper)
}

\section{ANALYSIS OF POLYPHENOL COMPOUNDS IN BETUNG BAMBOO SHOOTS (Dendrocalamus asper)}

\author{
Eklopas Padamani ${ }^{1)}$ James Ngginak $^{2)}$ Abner Tonu Lema ${ }^{3)}$ \\ 1) 2) Program Studi Pendidikan Biologi Universitas Kristen Artha Wacana Kupang \\ ${ }^{3)}$ Politeknik Pertanian Negeri Kupang \\ Email: james_ngginak@yahoo.com
}

diterima : 15 Maret 2020; dipublikasi : 30 Maret 2020

DOI: $10.32528 /$ bioma.v5i1.3688

\begin{abstract}
ABSTRAK
Kelompok senyawa polifenol memiliki kemampuan sebagai antioksidan. Dalam tulisan ini peneliti melakukan skrining polifenol pada sampel tunas bambu betung (Dendrocalamus asper) yang diperoleh dari desa Mataru Kabupaten Alor. Pengukuran kadar polifenol secara kualitatif menggunakan larutan $\mathrm{FeCl}_{3} 1 \%$ dan pengujian secara kuantitatif menggunakan metode spektrofotometeri UV-Vis (CE 2021). Hasil pengukuran secara kualitatif menunjukan bahwa pada sampel terkandung senyawa polifenol. Hal ini diperkuat dengan adanya indikator pembentukan warna coklat kehitaman yang pekat. Pengukuran secara kuantitatif menggunakan Spektrofotometri UV-Vis (CE 2021) menunjukan bahwa pada sampel terkandung senyawa polifenol dengan total kadar $8,065 \mathrm{mg} / \mathrm{L}$. Penelitian ini diharapkan dapat memberikan informasi bagi bidang farmakologi tentang tunas bambu betung sebagai salah satu sumber polifenol dan masyarakat tentang pemanfaatan tunas bambu betung sebagai salah satu sumber polifenol dalam pengawetan bahan makanan yang mudah teroksidasi.
\end{abstract}

Kata kunci : Antioksidan, Mataru, Polifenol, Tunas Betung

\section{ABSTRACT}

Polyphenols group of compounds has the ability as an antioxidant. In this paper, the researchers screened polyphenols on bamboo betung shoot samples (Dendrocalamus asper) obtained from the village of Mataru, Alor Regency. Qualitative measurement of polyphenol levels using $1 \% \mathrm{FeCl} 3$ solution and quantitative testing using the UV-Vis spectrophotometry method (CE 2021). Qualitative measurement results show that the sample contained polyphenol compounds. This is reinforced by the presence of an indicator for the formation of black-brown color. Quantitative measurements using UVVis Spectrophotometry (CE 2021) showed that the sample contained polyphenol compounds with a total content of $8.065 \mathrm{mg} / \mathrm{L}$. This research is expected to provide information for pharmacology about bamboo betung shoots as a source of polyphenols and also expected to educate the public about the use of bamboo betung shoots as a source of polyphenols in preserving food that is easily oxidized.

Keywords : Antioxidants, Polyphenols, Mataru, Bamboo Shoots 


\section{PENDAHULUAN}

Rebung merupakan tunas bambu muda yang muncul dari dalam tanah yang berasal dari akar rimpang maupun buku-buku. Menurut Haryani $d k k$ (2014), tunas muda yang tumbuh dari akar bambu berbentuk kerucut. Organ ini berwarna coklat keunguan tertutup miang halus dan tebal seperti beludru. Tunas bambu termasuk bambu betung (Dendrocalamus asper) dapat dimanfaatkan sebagai bahan makanan. Rebung oleh masyarakat dimanfaatkan sebagai nugget rebung (Wahanani, 2014). Rebung juga dapat digunakan sebagai bahan subtitusi dalam pembuatan krupuk (Rizkiyani $d k k$, 2016). Tunas atau rebung dapat dijadikan sebagai bahan subtitusi untuk pembuatan tepung (Howard $d k k$, 2014). Kandungan nutrisi penting seperti protein, serat, kalium dan karbohidrat ditemukan dalam tunas bambu (Wahanani, 2014).

Dewasa ini kebutuhan akan berbagai bahan alami sebagai sumber obat-obatan menjadi prioritas dunia medis. Hal ini karena obat herbal aman bagi pasien dan tidak menimbulkan efek samping. Menurut Mallo $d k k$ (2017), konsumsi obat herbal yang diperoleh langsung dari tumbuhan tidak menyebabkan efek samping. Tumbuhan pada dasarnya memiliki kandungan senyawa aktif yang bermanfaat bagi tubuh. Salah satu senyawa aktif dalam tumbuhan yang memiliki efek farmakologis adalah polifenol.

Polifenol adalah salah satu senyawa metabolik sekunder yang disintesis melalui metabolisme glukosa. Kelompok senyawa ini memiliki gugus hidroksil pada cincin benzene yang berperan sebagai antioksidan (Towaha, 2014). Senyawa polifenol memiliki daya antioksidan yang baik karena golongan ini dapat memberikan elekronnya untuk menetralkan elektron radikal bebas yang terbentuk dalam tubuh (Dhianawaty \& Ruslin, 2015). Menurut Kate (2014), Senyawa fenolik dari tanaman mempunyai kemampuan sebagai antioksidan, antiinflamasi, antiproliferasi, antimutagenik dan antimikrobial. Senyawa fenol juga memiliki peran dalam mencegah dan mengobati penyakit degeneratif, gangguan kognitif, kanker, penuaan dini dan gangguan sistem imun tubuh (Wahdaningsih $d k k, 2017$ ).

Sejauh ini analisis senyawa metabolik sekunder termasuk kadar polifenol dalam tunas atau rebung bambu betung belum banyak dipublikasikan. Penelitian oleh Soesanto (2018), menjelaskan bahwa pada rebung bambu kuning dan hijau mengandung fenol, flavonoid serta vitamin E. Dalam penelitian lain terkait komposisi rebung bambu menurut Kasi $d k k$ (2016), tunas bambu mengandung C organik dan giberelin yang 
penting untuk pertumbuhan tanaman. Selain itu ditinjau dari sisi medis, penelitian ini penting dilakakukan karena berperan memberikan informasi tambahan bagi dunia farmakologi tentang sumber polifenol dari tunas bambu betung. Penelitian ini juga diharapkan bermanfaat bagi industri bahan makanan dalam memanfaatkan rebung bambu betung sebagai sumber polifenol untuk pengawetan bahan makanan yang mudah teroksidasi.

Berdasarkan latar belakang diatas maka peneliti tertarik untuk melakukan penelitian dengan judul "Analisis Kandungan Polifenol Pada Ekstrak Tunas Bambu Betung (Dendrocalamus asper).

\section{METODE}

\section{Waktu dan Tempat}

Penelitian telah dilaksanakan di Laboratorium Eksakta Universitas Kristen Artha Wacana (UKAW) Kupang dan Laboratorium Politeknik Pertanian Negeri (POLITANI) Kupang pada tanggal 10 Oktober sampai tanggal 25 Oktober 2019.

\section{Alat dan bahan Alat}

Alat yang digunakan dalam penelitian ini adalah : Neraca analitik (Merk HWH), labu takar (Merk Pirex), Elenmeyer (Merk Herma), Beaker glass 500 mL (pirex), Tisu (Kelontong $08 \mathrm{Cbs),} \mathrm{Pipet} \mathrm{tetes} \mathrm{(Merk} \mathrm{globolab),} \mathrm{Tabung} \mathrm{reaksi} \mathrm{(Merk} \mathrm{Iwaki),} \mathrm{Botol}$ semprot (Merk Vitlab), Almunium foil (Merk Klin pak), Spektrofotometer (UV-Vis merk CE 2021), kertas saring (whatman no 42), kuvet, rotary evaporator (RE 100 Pro), Corong Buchner (Merk Herma), Blender (Merk Philips).

Bahan yang digunakan dalam penelitian ini adalah Etanol (pa) $\mathrm{FeCl} 3$ (pa) 1\%, pereaksi Folin Ciocalteu (pa), $\mathrm{Na}_{2} \mathrm{CO}_{3} 75 \%$ (Merk Sodium), asam galat (pa) 100 ppm, aquades dan sampel Rebung betung (Dendrocalamus asper) yang diperoleh dari Desa Mataru Timur Kecamatan Mataru Kabupaten Alor (NTT).

\section{Metode dan desain penelitian}

Metode penelitian yang digunakan dalam penelitian ini adalah deskriptif kualitatif dan kuantitatif serta desain penelitiannya adalah eksperimen. 


\section{Prosedur penelitian}

\section{Pengambilan Sampel}

Sampel tunas bambu betung (Dendrocalamus asper) diperoleh Desa Mataru Timur. Sampel selanjutnya dibersikan kemudian dimasukan dalam wadah (kantong plastik) selanjutnya dibawa untuk dianalisis di Laboratorium.

\section{Preparasi Sampel}

Sampel (tunas bambu) yang telah dicacah disimpan di tempat yang sejuk lalu dikeringanginkan di udara terbuka yang terlindung dari sinar matahai selama tujuh hari. Sampel yang sudah kering berwarna kecoklatan, selanjutnya ditimbang $250 \mathrm{~g}$ lalu dihaluskan dengan cara diblender untuk kepentingan proses ekstraksi (Asmara, 2017).

\section{Ekstraksi Sampel}

Sampel serbuk betung dimasukkan ke dalam beaker glass, selanjutnya sebanyak $100 \mathrm{~mL}$ pelarut etanol diberikan hingga semua sampel tampak terendam dalam pelarut. Sampel dimaserasi dalam jangka waktu 2x24 jam. Senyawa yang telah larut dalam pelarut akan disaring. Proses maserasi dapat dilakukan kembali apabila semua senyawa yang ditargetkan belum terkestrak secara menyeluruh. Hasil ekstrak yang diperoleh dikumplkan kemudian diuapkan menggunakan Rotary Vacuum Evaporator hingga diperoleh ekstrak etanol yang pekat.

\section{Uji kualitatif polifenol}

Pembuktian kualitatif kelompok polifenol dalam sampel rebung betung menggunakan larutan uji $\mathrm{FeCl}_{3}$ 1\%. Proses pengujian diawali dengan menyiapkan 2 mL ekstrak etanol kemudian tambahkan empat tetes larutan $\mathrm{FeCl}_{3} 1 \%$. Sampel dihomogenkan dan diamati. Apabila terbentuk warna coklat kehitaman dan hijau kehitaman, maka hal ini mengindikasikan dalam sampel mengandung senyawa polifenol (Alfian \& Susanti, 2012).

\section{Uji kuantitatif Polifenol}

\section{Pembuatan larutan standar (asam galat)}

Siapakan larutan asam galat 100 ppm dengan seri konsentrasi $0,5 \mathrm{~mL} ; 0,25 \mathrm{~mL}$; 0,75 mL; $1 \mathrm{~mL} ; 1,25 \mathrm{~mL} ; 1,5 \mathrm{~mL}$; masing-masing seri konsentrasi dimasukan ke dalam labu takar $50 \mathrm{~mL}$. Masing-masing labu takar ditambahkan $5 \mathrm{~mL}$ pereaksi volin Ciocalteau lalu dihomogenkan dan disimpan selama 4-8 menit. Setelah itu tambahkan 5 $\mathrm{mL} \mathrm{Na}_{2} \mathrm{CO}_{3} 75 \%$. Campuran dihomogenkan kemudian ditambahkan lagi aquades 
hingga tanda batas. Bahan akan didiamkan selama 2 jam dan akan diukur serapanya menggunakan spektrofotometer UV-Vis. Pengukuran dilakukan tiga kali ulangan.

Penentuan Panjang Gelombang Maksimum

Larutan induk standar asam galat $100 \mathrm{ppm}$ diambil 0,5 mL dimasukkan ke dalam labu ukur $100 \mathrm{~mL}$, lalu ditambahkan 0,5 mL pereaksi Follin- Ciocalteu, $4 \mathrm{~mL} \mathrm{Na} \mathrm{CO}_{3}$ 7,5\% serta aquadest hingga tanda batas. Larutan diinkubasi selama 30 menit. Selanjutnya ukur serapan dengan menggunakan spektrofotometer UV-Vis pada panjang gelombang 500-750 $\mathrm{nm}$.

\section{Pembuatan Kurva Kalibrasi Polifenol}

Larutan standar asam galat 100 ppm yang telah disiapkan akan dibuat konsentrasi $0 ; 0,5 ; 1 ; 1,5 ; 2 ; 2,5 ; 3$. Sebanyak $0,5 \mathrm{~mL}$ reagen folin Ciocalteau ditambahkan ke dalam masing-masing konsentrasi lalu dihomogenkan serta didiamkan 4-8 menit. Setelah itu larutan standar diberikan 5,0 $\mathrm{mL} \mathrm{Na}_{2} \mathrm{CO}_{3}$ serta aquades $10 \mathrm{~mL}$. Sebelum pengukuran absorbansi, larutan didiamkan selama dua jam pada suhu ruang. Kemudian dibuat kurva kalibrasi hubungan antara konsentrasi asam galat $(\mu \mathrm{g} / \mathrm{ml})$ dengan absorbansi (Alfian \& susanti, 2012).

\section{Penetapan Konsentrasi polifenol dari sampel Rebung betung}

Sebanyak $4 \mathrm{~mL}$ Filtrat ditambahkan ke dalam labu takar $25 \mathrm{~mL}$ setelah itu ditambahkan pula dengan pereaksi folin Ciocalteau dan dihomogenkan selama delapan menit. Kemudian ditambahkan $6 \mathrm{~mL} \mathrm{Na}_{2} \mathrm{CO}_{3} 75 \%$ dikocok kemudian ditambahkan aquades hingga tanda batas, lalu didiamkan selama satu jam dan diukur serapanyan menggunakan spektrofotometer UV-Vis pada panjang gelombang $690 \mathrm{~nm}$. Pada tahap ini dilakukan tiga kali pengulangan dan penentuan konsentrasi polifenol menggunakan persamaan regresi linear $\mathrm{y}=\mathrm{ax}+\mathrm{b}$.

\section{Teknik Analisis Data}

Data dianalisis berdasarkan hasil perhitungan rumus regresi linear yaitu $\mathrm{Y}=\mathrm{ax}+\mathrm{b}$. Perhitungan data pada rumus regresi linear mengacu kepada nilai absorbansi dan konsentrasi larutan standar.

Keterangan.

$\mathrm{y}=$ Variabel dependen (nilai yang diorediksikan)

$\mathrm{a}=$ Konsentrasi (nilai $\mathrm{Y}$ apabila $\mathrm{X}=0$ )

$\mathrm{x}=$ Variabel independen

$\mathrm{b}=$ Koefesien regresi (nilai peningkatan ataupun penurunan) 


\section{HASIL DAN PEMBAHASAN}

\section{Uji Kualitatif Polifenol dalam Rebung Betung}

Penentuan kandungan polifenol pada rebung betung dapat dilakukan dengan uji kualitatif atau uji pendahuluan $\mathrm{FeCl}_{3} 1 \%$. Tujuan analisis ini adalah untuk membuktikan kandungan polifenol dalam ekstrak kering tunas betung. Data hasil pengamatan kandungan fenolik pada rebung atau tunas betung secara kualitatif dapat dilihat pada tabel satu berikut.

Tabel 1. Hasil Analisis Kualitatif Polifenol dalam rebung betung

\begin{tabular}{lllllll}
\hline Sampel & Uji & Pereaksi & Teori & $\begin{array}{l}\text { Hasil } \\
\text { Pengamatan }\end{array}$ & Gambar & Kesimpulan \\
& Kualitatif & & & Warna & + \\
$\begin{array}{l}\text { Ekstrak etanol } \\
\text { tunas betung }\end{array}$ & Polifenol & $\mathrm{FeCl}_{3} 1 \%$ & $\begin{array}{l}\text { Hijau, } \\
\text { merah, } \\
\text { ungu, biru, } \\
\text { atau hitam }\end{array}$ & $\begin{array}{l}\text { coklat } \\
\text { menjadi } \\
\text { hitam pekat }\end{array}$ \\
\end{tabular}

Sumber : Hasil penelitian (2019)

Keterangan : $+=$ Mengandung polifenol

Berdasarkan hasil pengamatan, data menunjukan bahwa sampel positif mengandung senyawa fenolik yang ditandai dengan adanya perubahan warna seperti warna coklat kehitaman. Warna yang terbentuk sebagai akibat dari komposisi larutan $\mathrm{FeCl}_{3} 1 \%$ yang bereaksi dengan senyawa fenolik. Dengan kata lain bahwa perubahan warna yang terjadi akibat reaksi antara gugus fungsi hidroksil fenol dengan larutan pereaksi $\mathrm{FeCl}_{3}$. Menurut Indra $d k k$ (2017), senyawa fenol dalam sampel dibuktikan melalui indikator terbentuknya warna sampel berupa hijau kecoklatan dan hitam setelah diberikan perlakuan $\mathrm{FeCl}_{3}$. Dalam hal ini peraksi $\mathrm{FeCl}_{3}$ berperan sebagai katalis.

Penelitian oleh Adhayanti $d k k$ (2018), menjelaskan bahwa ekstrak kulit pisang raja sebanyak $1 \mathrm{~mL}$ dengan pereaksi $\mathrm{FeCl}_{3} 10 \%$ menyebabkan perubahan warna menjadi biru kehitaman atau hitam kehijauan. Hal ini menunjukan bahwa pada sampel mengandung senyawa polifenol. Menurut Ahmad dkk (2015), uji kualitatif menggunakan $\mathrm{FeCl}_{3}$ sebagai pereaksi jika suatu bahan Positif mengandung fenol apabila terbentuk noda berwarna hijau, merah, ungu, biru hingga hitam yang pekat.

Uji Kuantatif Polifenol Pada Sampel Rebung Betung

Penentuan total kadar fenolik secarah kuantitatif pada sampel rebung betung dilakukan dengan menggunakan metode spektrofotometer UV-Vis. Data kurva baku asam galat dapat dilihat pada gambar satu di bawah ini. 


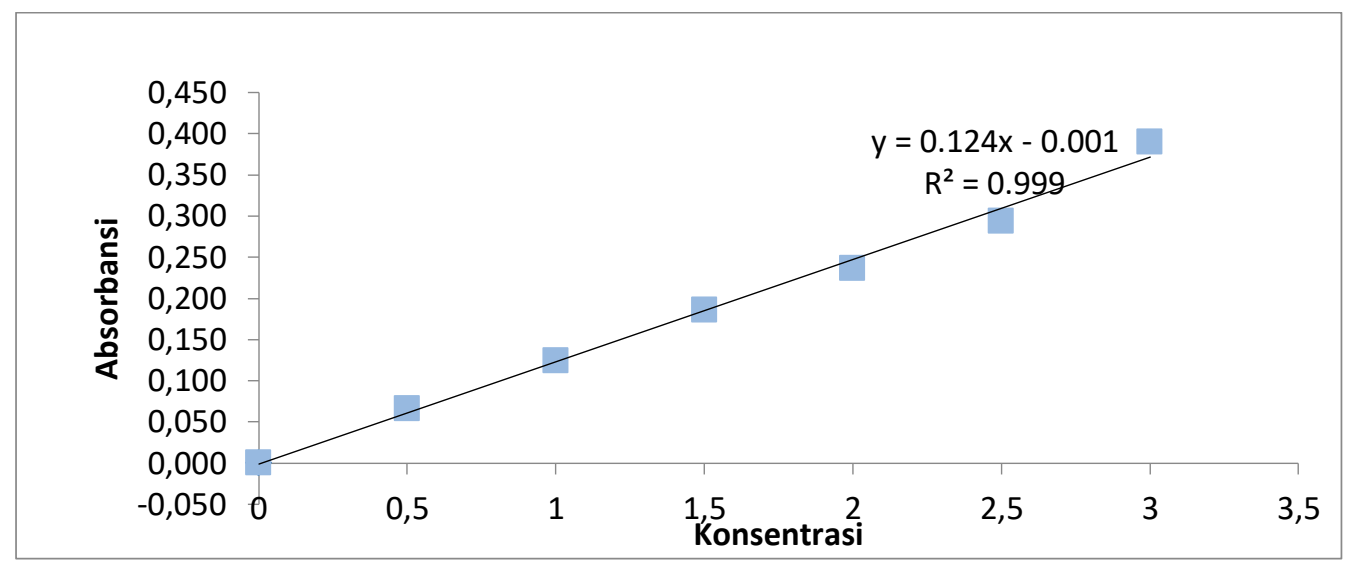

Gambar 1. Kurva baku asam galat dalam penetapan total fenolik

Tolal kadar polifenol dalam sampel rebung betung dapat dihitung dengan menggunakan persamaan regresi linear $y=0,124 x+0,001$. Nilai linearitas dari penentuan total polifenol adalah 0,999. Nilai linearitas ini menunjukan hubungan antara konsentrasi sampel dan absorbansi sampel. Jika nilai linearitas atau $r$ mendekati satu atau sama dengan satu menunjukan persamaan tersebut semakin baik dan berkorelasi positif atau linear (Ahmad $d k k, 2015$ ). Semakin tinggi konsentrasi yang digunakan maka semakin tinggi pula absorbansi yang diperoleh. Panjang gelombang maksimum untuk mengukur absobansi larutan standar asam galat dan beberapa konsentrasi sampel adalah $690 \mathrm{~nm}$.

Pengukuruan total kadar fenol dalam sampel rebung betung dilakukan tiga kali atau tiga kali pengulangan dengan harapan diperoleh data yang lebih baik. Data replikasi kadar polifenol dapat dilihat pada tabel dua berikut.

Tabel 2. Hasil Analisis Kuantitatif Polifenol dalam Sampel

\begin{tabular}{lccccc}
\hline Sampel & $\begin{array}{c}\mathrm{y}=\text { Absorbansi } \\
\text { sampel }\end{array}$ & $\begin{array}{c}\text { Nilai a } \\
\text { (slope) }\end{array}$ & $\begin{array}{c}\text { Nilai b } \\
\text { (intersept) }\end{array}$ & $\begin{array}{c}\mathrm{X}=\text { konsentrasi } \\
\text { polifenol sampel } \\
(\mathrm{mg} / \mathrm{L})\end{array}$ & $\begin{array}{c}\text { Faktor } \\
\text { pengenceran } \\
(10 \mathrm{x} \mathrm{mg} / \mathrm{L})\end{array}$ \\
\hline I & 0,101 & 0,124 & 0,001 & 0,823 & 8,226 \\
II & 0,100 & 0,124 & 0,001 & 0,815 & 8,145 \\
III & 0,099 & 0,124 & 0,001 & 0,806 & 8,065 \\
\hline Rata-rata & 0.3 & 0.372 & 0.003 & 2.444 & 24.433 \\
\hline Total & \multicolumn{5}{c}{$8,065 \mathrm{mg} / \mathrm{L}$} \\
polifenol & \multicolumn{5}{c}{ Sumber : Hasil penelitian $(2019)$}
\end{tabular}

Penentuan total kandungan polifenol pada ekstrak kering rebung betung diukur menggunakan metode spektrofotometri dengan mengaju pada prinsip kerja FollinCiocalteu. Pembuktian kandungan polifenol menggunakan pereaksi reagen FolinEklopas Pandamani, et at., Analisis Kandungan ... 
Ciocalteau karena pereaksi ini dapat bereaksi dengan kelompok senyawa polifenol membentuk larutan pekat yang dapat diukur absorbansinya. Semakin tinggi atau pekat konsentrasi sampel maka semakin tinggi pula nilai absorbansinya (Wijayanti, 2016). Pereaksi Folin akan mengoksidasi gugus fungsional polifenol (Adhayanti, 2018).

Kelompok senyawa fenol akan bereaksi dengan pereaksi Folin-Ciocalteau apabila kondisi yang terbentuk adalah dalam suasana basa. Kondisi basa memungkinkan terjadi disosiasi proton pada senyawa fenol menjadi ion fenolat. Kondisi basa dapat dibentuk dengan menggunakan $\mathrm{Na} 2 \mathrm{CO}_{3}$. Akibat dari adanya reaksi ini terbentuk warna biru. Ion fenolat yang merombak asam heteropoli menjadi kompleks momolibdenum-tungsten menyebabkan warna biru yang dihasilkan semakin pekat (Adhayanti, 2018).

Berdasarkan hasil uji kuantitatif menggunakan spektrofometer, data menunjukan bahwa pada tunas atau rebung bambu betung mengandung total senyawa polifenol sebesar 8,065 mg/L. Dengan demikian jelas bahwa rebung betung merupakan salah satu sumber polifenol. Penapisan senyawa polifenol dan senyawa metabolik sekunder lain pada rebung betung sendiri sejauh ini belum banyak dipublikasikan. Hasil penapisan polifenol pada rebung betung jika dibandingkan dengan beberapa penelitian terkait polifenol menunjukan adanya potensi sumber polifenol. Menurut penelitian oleh Soesanto (2018), pada tunas atau rebung bambu kuning dan hijau mengandung fenol (2,3385\% dan 1,9329\%), flavonoid dan vitamin E. Menurut Dhianawaty \& Ruslin (2015), ditemukan pada akar alang-alang terkandung polifenol sebanyak 1,53\%. Ahmad dkk (2015), melaporkan bahwa pada daun dan buah Patikala mengandung polifenol sebesar 6,29 \% b/b dan 2,29\% b/b. Selain itu menurut Zuraida dkk (2017), melaporkan bahwa kulit batang Pulai memiliki kadar fenol sebesar $51.50 \mathrm{mg}$ GAE/g ekstrak. Kombinasi ekstrak pegagan dan buah makhota dewa memiliki kandungan fenol sebesar 3,67 mg GAE/100 g ekstrak (Purgiyanti $d k k, 2019$ ).

Kadar polifenol yang diperoleh dalam rebung betung tidak menutup kemungkinan dipengaruhi oleh beberapa factor seperti proses ekstraksi, lingkungan dan sifat kimia dari polifenol itu sendiri. Menurut Proklamasiningsih $d k k$; Alfian \& Susanti (2018, 2012) kandungan biomassa bahan uji dapat dipengaruhi oleh faktor seperti proses ektraksi, unsur hara, jenis dan sifat kimia dari biomasa bahan uji tersebut. Polifenol merupakan salah satu senyawa yang mudah teroksidasi akibat aktivitas enzim polifenol 
oksidase (Towaha, 2014). Oleh karena itu dalam preparasi, ekstraksi atau proses analisis perlu disiapkan dengan baik agar tidak mengurangi kadar polifenol dalam sampel.

Golongan senyawa polifenol merupakan senyawa metabolik sekunder yang memiliki gugus hidroksil $(-\mathrm{OH})$ pada rantai hidrokarbon. Keberadaan gugus ini menjadikan polifenol sebagai senyawa yang memiliki sifat antioksidan yang baik (Dhianawaty \& Ruslin, 2015). Senyawa fenolik terbentuk dari jalur metabolisme asam sikimat dan fenil propanoid (hasil metabolism glukosa) (Kate, 2014). Menurut Proklamasiningsih $d k k$ (2018), sintesis polifenol terjadi melalui jalur asam sikimat yang bermula dari kondensasi antara phosphoenolpyruvate (PEP) dan erythose 4-phospate membentuk asam amino aromatik fenilalanin dan tirosin. Fenilalanin merupakan substrat untuk enzim phenylalanine ammonia-lyase (PAL) yang berfungsi mengkatalisis reaksi pertama pada jalur fenilpropanoid. Reaksi ini juga mengarah pada pembentukan sebagian besar senyawa polifenol. Senyawa fenol sederhana yang terkandung dalam tumbuhan seperti benzoquinone, asam fenolat, asetofenon, naftokuinon, xanton, bioflavonoid kumarin, stilben, turunan tirosin, asam hidroksi sinamat, flavonoid, lignan dan tanin. Senyawa polifenol juga terdiri dari beberapa subkelas yakni flavonol, isoflavon (dalam kedelai), flavanon, antosianidin, katekin dan biflavan. Turunan dari katekin seperti epikatekin, epigalo-katekin, apigalo-katekin galat dan quercetin yang umumnya ditemukan dalam teh dan apel. Berdasarkan sifat kelarutannya senyawa fenol alami dapat diklasifikasikan dalam dua kelompok yaitu kelompok lipofilik dan hidrofilik (Dhianawaty \& Ruslin, 2015). Berikut ini jalur biosintesis polifenol pada tanaman kakao. 


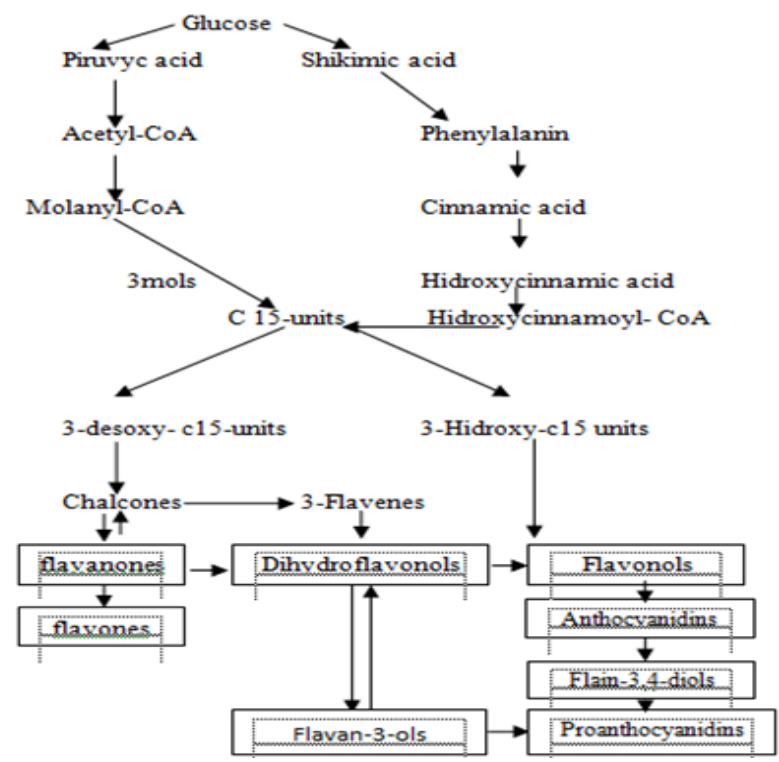

Gambar 2. Salah satu contoh jalur biosintesis polifenol pada tanaman kako (Towaha, 2014).

Polifenol memiliki sifat mudah teroksidasi jika terpapar oleh panas atau oksigen. Kelompok senyawa polifenol dapat mengalami oksidasi akibat aktifitas enzim polifenol oksidase (Towaha, 2014). Akibat dari reaksi oksidasi ini dapat kita amati terjadi perubahan warna pada bahan makanan saat pengirisan (terbentuk warna coklat). Hal ini pula yang terjadi pada irisan rebung atau tunas betung saat persiapan untuk proses ekstrak. Berikut ini salah satu contoh proses oksidasi polifenol pada daun teh.

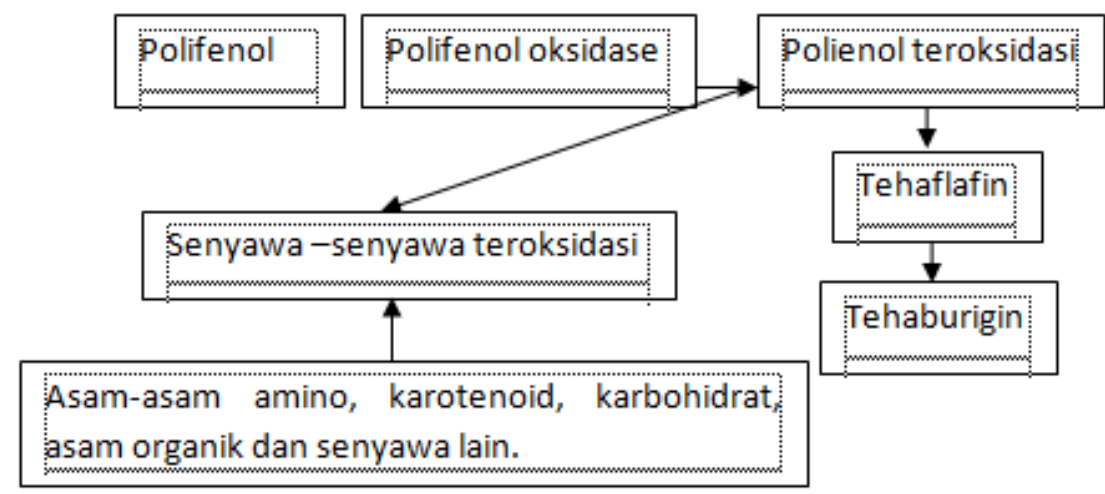

Gambar 3. Contoh proses oksidasi polifenol pada daun teh (sumber ; Bayani \& Mujaddid, 2015)

Gugus hidroksil yang terdapat dalam polifenol membuat senyawa ini mudah teroksidasi namun pada sisi lain memiliki daya antioksidan yang kuat. Aktivitas antioksidan berperan penting dalam memelihara kesehatan tubuh manusia dari pengaruh radikal bebas (Ikram $d k k$, 2017). Antioksidan adalah senyawa yang memiliki sifat 
menghambat pembentukan radikal bebas akibat oksidasi. Mekanisme senyawa fenolik sebagai antioksidan terjadi melalui kemampuan donor elektron dari fenol untuk berpasangan dengan elektron radikal bebas dalam tubuh (Kate, 2014). Elektron radikal bebas yang tidak berpasangan akan merampas atau mengikat elektron sel tubuh sebagai pasangannya sehingga menimbulkan kanker (Huliselan $d k k, 2015)$. Molekul antioksidan secara alami terdapat di dalam tubuh, namun kemampuan tubuh menghasilkan antioksidan menurun seiring dengan bertambahnya usia. Oleh karena itu untuk menjaga dan memenuhi antioksidan dalam tubuh maka perlu ditingkatkan melalui asupan bahan makanan seperti sayur dan buah-buahan, ikan dan daging.

Radikal bebas sendiri merupakan senyawa hasil oksidasi yang memiliki elektron tidak berpasangan atau bebas. Pemicu terbentuknya radikal bebas dalam tubuh adalah hasil metabolisme tubuh dan pengaruh faktor eksternal seperti asap rokok, sinar ultraviolet, zat kimia makanan dan polutan mesin (Huliselan $d k k, 2015)$

Menurut Dhianawaty \& Ruslin (2015), beberapa senyawa dari polifenol mempunyai aktivitas anti hipertensi dan anti penuaan. Golongan senyawa fenol juga memiliki manfaat sebagai anti kanker, anti peradangan, anti bakteri dan anti degradatif molekuler. Towaha (2014), menjelaskan bahwa senyawa polifenol mampu mengatasi penyakit seperti kanker, diabetes mellitus, anti depresi, mencegah gigi berlubang, cardiovascular, meningkatkan sistem imun dan kognitif. Menurut Armin dkk (2014), Polifenol juga berperan dalam memberikan warna pada daun saat musim gugur. Golongan senyawa polifenol adalah senyawa aktif yang banyak ditemukan pada tumbuhan seperti pada kacang-kacangan, teh hijau, teh putih, anggur merah, minyak zaitun, cokelat, jeruk dan buah delima. Kadar polifenol yang tinggi dapat juga ditemukan pada kulit buah seperti pada anggur, apel dan jeruk (Zuraida dkk, 2017).

\section{KESIMPULAN DAN SARAN}

Merujuk pada data hasil penelitian maka, total kandungan polifenol yang terdapat pada tunas atau rebung bambu betung $8,065 \mathrm{mg} / \mathrm{L}$. Data ini juga menjelaskan bahwa setiap gram ekstrak rebung bambu betung terdapat polifenol yang setara dengan 8,145 mg asam galat.

Berdasarkan data hasil penelitian, maka peneliti menyarankan dilakukan kajian terkait beberapa turunan polifenol seperti lignin, melanin, tanin, flavonoid serta katekin 
pada rebung atau tunas bambu betung. Perlu juga dilakukan skrining senyawa metabolik sekunder lainnya seperti alkaloid dan terpenoid. Penulis juga menyarankan melakukan uji daya antioksidan dan antibakteri ekstrak rebung betung yang diperoleh dari Desa Mataru Timur Kecamatan Mataru Kabupaten Alor Nusa Tenggara Timur (NTT). (Semua saran dapat dilakukan dalam sediaan sampel basah dan kering serta berdasarkan lokasi yang berbeda atau ketinggian).

\section{DAFTAR PUSTAKA}

Adhayanti, I., Abdullah, T., \& Romantika, R. (2018). Uji Kandungan Total Polifenol dan Flavonoid Ekstrak Etil Asetat Kulit Pisang Raja (Musa paradisiaca var. sapientum). Jurnal Media Farmasi, 14(1), 146-152

Ahmad, A. R., Juwita, J., \& Ratulangi, S. A. D. (2015). Penetapan Kadar Fenolik dan Flavonoid Total Ekstrak Metanol Buah dan Daun Patikala (Etlingera elatior (Jack) R.M.SM). Jurnal Pharmaceutical Sciences and Research, 2(1), 1-10.

Alfian, R., \& Susanti, H. (2012). Penetapan Kadar Fenolik total Ekstrak Metanol Kelopak Bunga Rosella Merah (Hibiscus sabdariffa Linn) dengan Variasi tempat Tumbuh secara Spektrofotometri. Jurnal Ilmiah Kefarmasian. 2(1) 73-80.

Armin, F., Ermadanis, \& Rasyid, R. (2014). Analisis Senyawa Fenolat dan Uji Aktivitas Antioksidan Buah Markisa ( Passiflora edulis Sims) secara Spektrofotometri Visibel. Jurnal Farmasi Higea, 6(2), 117-128.

Asmara, A. P. (2017). Uji Fitokimia Senyawa Metabolit Sekunder Dalam Ekstrak Metanol Bunga Turi Merah (Sesbania grandiflora L. Pers). Jurnal Al-Kimia, 5(1), $48-59$

Bayani, F, \& Mujaddid, J. (2015). Analisis Fenol Total Teh Hijau Komersial ( Camellia sinensis L ). Jurnal Ilmiah Pendidikan Kimia "Hidrogen". 3(2), 318-323.

Dhianawaty, D., \& Ruslin. (2015). Kandungan Total Polifenol dan Aktivitas Antioksidan dari Ekstrak Metanol Akar Imperata cylindrica ( L ) Beauv. (Alangalang). Majalah Kedokteran Bandung, 47(1), 60-64.

Haryani, M., Widawati, L., Sari, R. (2014). Tepung Rebung Termodifikasi Sebagai Substituen Terigu Pada Pembuatan Donat Kaya Serat. Jurnal Agritepa, I(1), 5262. 
Howard Patty, R., Semadi Antara, N., \& Arnata, I. (2014). Pengaruh Bagian Rebung dan Perlakuan Pendahuluan Terhadap Karakteristik Tepung dari Rebung Bambu Tabah (Gigantochloa nigrociliata BUSE - KURZ). Jurnal Rekayasa Dan Manajemen Agroindustri, 2(2), 87-98.

Huliselan, Y. M., Runtuwene, M. R. J., \& Wewengkang, D. S. (2015). Aktivitas Antioksidan Ekstrak Etanol, Etil Asetat, \& N-Heksan dari Daun Sesewanua (Clerodendron squamatum Vahl.). Jurnal Ilmiah Farmasi UNSRAT, 4(3), 155163.

Ikram, K. D., Jayali, A. M., Umar, S., \& Sasmita, I. (2017). Penentuan Total Fenolik Dan Aktivitas Antioksidan Ekstrak Etanolik Daun Samama (Anthocephalus Macrophylus) Asal Ternate, Maluku Utara. Jurnal Kimia Mulawarman,15(1),1118

Indra Setyawan, E. (2017). Studi Pelepasan Senyawa Polifenol Ekstrak Daun Sirih (Piper Betle L.) Matrik Patch Mukoadesif Methocel*A15. Jurnal Ilmiah Farmasi, $13(1), 1-7$

Kasi, P. D., Suaedi, S., \& Angraeni, F. (2018). Pemanfaatan Pupuk Organik Cair Rebung Bambu untuk Pertumbuhan Kangkung Secara Hidroponik. Biosel: Biology Science and Education, 7(1), 42-48

Kate, D. I. (2014). Penetapan Kandungan Fenolik Total Dan Uji Aktivitas Antioksidan dengan Metode DPPH (1,1-Diphenyl-2-Pikrilhydrazil) Ekstrak Metanolik Umbi Bidara Upas (Merremia Mammosa (Lour) Hallier F). Fakultas Farmasi Universitas Sanata Dharma Yogyakarta, 1-123.

Mallo, M., Sabuna Ch. A., James, N. (2017). Tumbuhan Obat untuk Kesehatan Reproduksi di Kecamatan Kuatnana Kabupaten TTS. Jurnal Media Farmasi Indonesia. 12(2), 1233-1247

Purgiyanti, Purba, A. V., \& Winarno, H. (2019). Penentuan Kadar Fenol Total dan Uji Aktivitas Antioksidan Kombinasi Ekstrak Herba Pegagan (Centella asiatica L. Urban) dan Buah Mahkota Dewa (Phaleria macrocarpa (Scheff.) Boerl.). Jurnal Ilmiah Farmasi, 8(2), 40-45.

Proklamasiningsih, E., Budisantoso, I., \& Maula, I. (2019). Pertumbuhan dan Kandungan Polifenol Tanaman Katuk (sauropus androgynus (L.) Merr) pada 
Media Tanam dengan Pemberian Asam Humat. Al-Kauniyah: Jurnal Biologi, 12(1), 96-102

Rizkiyani, N., Kamal, R., \& Hamid, Y. Heirina. (2016). Pengaruh penambahan rebung betung terhadap karakteristik organoleptik dan tingkat penerimaan pada konsumen kerupuk. Jurnal Ilmiah Mahasiswa Pendidikan Kesejahteraan Keluarga, $1(1), 25-31$.

Soesanto, E. (2018). Compounds Antioxide of Extract Yellow and Green Bamboo Shoot. Jurnal Media Keperawatan Indonesia, Vol 1(No.1), 42-47

Towaha, J. (2014). Kandungan Senyawa Polifenol Pada Biji Kakao Dan Kontribusinya Terhadap Kesehatan. Jurnal Sirinov, Vol. 2 (No 1), 1-16

Wahanani, E. D. (2014). Pemanfaatan Rebung (tunas bambu) menjadi Nugget dengan Penambahan Kunyit sebagai Pengawet Alami.FKIP Muhammadiyah Surakarta.116

Wahdaningsih, S., Wahyuono, S., Riyanto, S., \& Murwanti, R. (2017). Penetapan Kadar Fenolik Total Dan Flavonoid Total Ekstrak Metanol Dan Fraksi Etil Asetat Kulit Buah Naga Merah (Hylocereus polyrhizus ((F.A.C.Weber) Britton Dan Rose). Jurnal Ilmiah Farmasi . UNSRAT, 6(3), 2302-2493.

Wijayanti N. M. (2016). Uji Aktifitas antioksidan dan Penetapan Kadar Fenolik Total Ekstrak Etanol Buah Buni (Antidesma bunius (L.) Spreng) dengan Metode 2,2Diphenyl-1-Picrylhydrazyl (DPPH) dan Metode Folin-Ciocalteu. Jurnal IOSR Journal of Economics and Finance, 3(1), 1-103

Zuraida, Sulistiyani, Sajuthi, D., \& Suparto, I. H. (2017). Fenol ,Flavonoid, dan Aktivitas Antioksidan pada Kulit Batang Pulai (Alstonia scholaris R . Br). Jurnal Penelitian Hasil Hutan. 35(3), 211-219. 